\title{
Physiological Studies on Cancer irroratus Larvae. I. Effects of Temperature and Salinity on Survival, Development Rate and Size*
}

\author{
D. Michael Johns \\ United States Environmental Protection Agency, Environmental Research Laboratory, South Ferry Road, Narragansett, RI \\ 02882, USA \\ and \\ Belle W. Baruch Institute for Marine Biology and Coastal Research, University of South Carolina, Columbia, SC 29208, USA
}

\begin{abstract}
Larvae of the rock crab Cancer irroratus were found to be eurythermal and stenohaline during development. Complete development occurred between $10^{\circ}$ and $24^{\circ} \mathrm{C}$ in $30 \% \mathrm{~S}$. Survival to the megalopa stage ranged from $20 \%$ (at $10^{\circ} \mathrm{C}$ ) to $83 \%$ (at $24^{\circ} \mathrm{C}$ ). Development was successful in 25 , 30 and $35 \% \mathrm{~S}$ at $15{ }^{\circ} \mathrm{C}$, but survival exceeded $50 \%$ only in 30 and $35 \% \mathrm{~S}$. Temperature and salinity significantly influenced molt frequency, intermolt duration and larval size. Maximum growth at metamorphosis was found at the mid-range of the thermal tolerance limits $\left(15^{\circ}-18^{\circ} \mathrm{C}\right)$. Comparison of these laboratory-determined data on survival and growth with available field data on the life history of C. irroratus suggests that the majority of larvae are released during that portion of the spawning period when larval wastage would be minimized and recruitment to the parental and regional populations would be maximized.
\end{abstract}

\section{INTRODUCTION}

Temperature and salinity effects on marine invertebrates have been reviewed in 'Marine Ecology', Volume I (Kinne, 1970, 1971). Most benthic crustaceans produce pelagic larvae at a predictable time of the year. For some crustaceans the breeding period is protracted (Williams, 1965; Mileikovsky, 1970) with larvae released at different times of the spawning season, encountering waters which have changed temporally in their environmental characteristics. Although environmental conditions within any portion of the spawning season are usually not directly lethal (Thorson, 1950), they may act as a sublethal stress altering development and growth patterns enough to be indirectly responsible for larval losses. Mortality due to the sublethal effects of environmental conditions on development and growth include a reduced ability to compete effectively for food resources and successfully avoid planktonic predators (Strathmann,

\footnotetext{
- Contribution No. 197 from EPA Environmental Research Laboratory. Narragansett, Rhode Island and Contribution No. 373 from the Belle W. Baruch Institute for Marine Biology and Coastal Research
}

1977). In addition to temporal changes in the environment which occur during the spawning season, larvae may also experience spatial differences in water conditions depending upon the degree to which they are dispersed by currents during development. Larval losses associated with dispersal include those mentioned above, as well as the possibility of being carried into environments unfit for survival (Thorson, 1950; Strathmann, 1977).

Two of the more important environmental parameters which change with time and distance are temperature and salinity. Since temperature and salinity are considered 'dominant ecological factors' in controlling the survival, rate of development and growth in marine organisms (Kinne, 1970, 1971; Alderdice, 1972), it might be expected that the chances of completing the pelagic larval phase and early settlement in the benthic population would depend largely on the degree to which these two variables change during larval development. Adequate recruitment of juveniles to the benthic population would be dependent on the synchronization of peak spawning to a time when environmental conditions within and surrounding the spawning grounds are optimal for larval development. 
This study was done to determine the interrelationship between temperature - salinity conditions and the development, physiological capacity, bioenergetics and size of Cancer irroratus larvae. Temperature and salinity values chosen were similar to those encountered by rock crab larvae developing in temperate waters of the eastern coast of USA. The results of the physiological and bioenergetic studies will be presented elsewhere.

\section{MATERIALS AND METHODS}

The flow-through mass-culture system (Fig. 1) used in this study consisted of a 9.5 l pilot separatory funnel (Ace Glassware*) fitted with an acrylic inner sleeve having a $145 \mu \mathrm{m}$ screen bottom. Larvae to be cultured for the growth studies were maintained within this

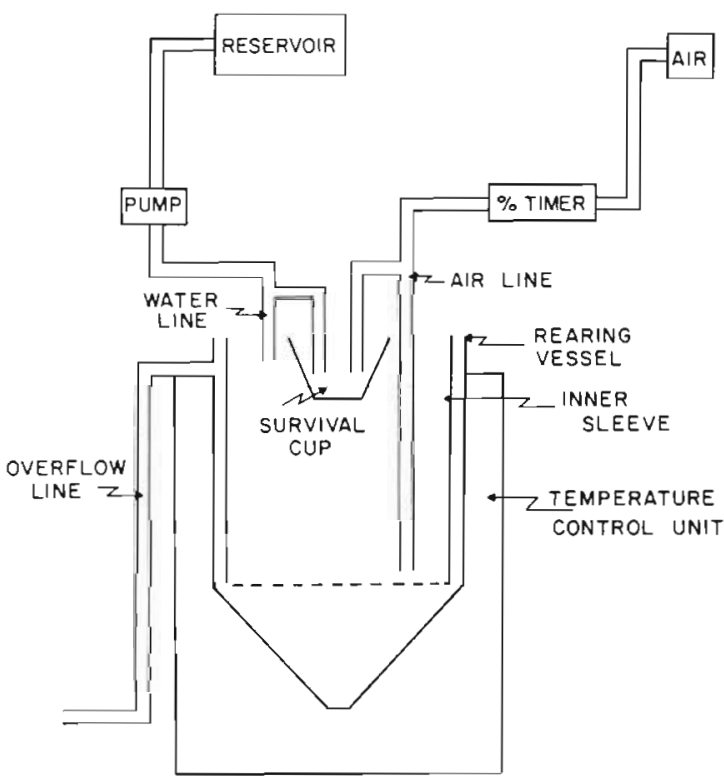

Fig. 1. Schematic view of the flow-through system used to mass-culture Cancer irroratus larvae

inner sleeve, while larvae which were to be used in determining survival and development rates were maintained in a $150 \mathrm{ml}$ screen-bottomed (145 $\mu \mathrm{m})$ plastic cup suspended within the larger chamber. The densities in both the survival cups and mass-culture chambers were identical, the survival cup being simply of reduced size.

Thermal regimes within the culture vessels were maintained within $\pm 0.75 \mathrm{C}^{\circ}$ of the desired temperature using a temperature-regulated bath (Instant Oceans, Inc. "). Water from a 19 l reservoir was metered

\footnotetext{
- Reference to trade names does not imply endorsement by the United States Environmental Protection Agency
}

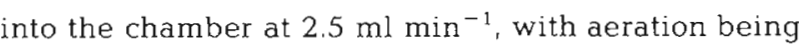
maintained on an intermittent basis using a percentage timer (Series 451, Cramer Electronics*). Preliminary experiments indicated no differences in survival between continuously aerated and intermittently aerated cultures (5 s every 15 s cycle), however larvae cultured to the megalopa stage in intermittent aeration were significantly heavier $(460 \pm 38 \mu \mathrm{g})(\mathrm{P} \leq 0.05)$ than those maintained with continuous aeration ( 378 $\pm 30 \mu \mathrm{g})$. Therefore, aeration for the definitive experiments was provided $5 \mathrm{~s}$ for every $15 \mathrm{~s}$ cycle using the percentage timer.

Gravid Cancer irroratus were collected by otter trawl from the West Passage of Narragansett Bay, Rhode Island, USA between December and May, 1977-1979. Females with undamaged egg masses were brought into the laboratory and maintained in unfiltered Narragansett Bay water (approx. $4{ }^{\circ} \mathrm{C}$ and $30 \% \mathrm{~S}$ ). When larvae were needed for experimentation, a gravid female was placed in $30 \%$ S seawater that was gradually brought to $15^{\circ} \mathrm{C}$ over a $24 \mathrm{~h}$ period. These conditions $\left(15^{\circ} \mathrm{C} / 30 \% \mathrm{~S}\right)$ were considered the optimum for final embryo incubation and hatching (Sastry, 1970).

After hatching, the zoeae were maintained in the flow-through culture systems. Approximately 500 Stage I zoeae were initially placed in each of the mass culture chambers with an additional 20 zoeae placed in the survival cup and subsequently maintained at one of the following temperature-salinity regimes: $10{ }^{\circ} \mathrm{C} / 30 \% \mathrm{~S} ; 15{ }^{\circ} \mathrm{C} / 25 \% \mathrm{~S} ; 15^{\circ} \mathrm{C} / 30 \% \mathrm{~S} ; 15^{\circ} \mathrm{C} / 35 \%$ $\mathrm{S} ; 18^{\circ} \mathrm{C} / 30 \% \mathrm{~S} ; 21^{\circ} \mathrm{C} / 30 \% \mathrm{~S} ; 24^{\circ} \mathrm{C} / 30 \%$ S. Available space did not allow for the maintenance of all 8 culture conditions at once, so only 3 or 4 rearing conditions were run at a time. One of these was always $15^{\circ} \mathrm{C} / 30 \% \mathrm{~S}$, which served as an internal standard for the experiment. Using the design described, each experimental culture condition was duplicated once, except for the $15{ }^{\circ} \mathrm{C} / 30 \% \mathrm{~S}$ condition which was repeated for a total of 5 runs. Because this design did not allow for the maintenance of larvae in all temperature and salinity combinations using a single hatch of larvae, a one-way analysis of variance was used to determine if there were significant differences in the size of the larvae at hatching from the five hatches used in the experiments. If a significant difference was found, data obtained from those hatches were not used in any of the analyses.

Larval development was followed to the megalopa stage. Survival cups were checked daily for mortality and evidence of molting. Moribund larvae were removed and staged. The remaining larvae in both the survival cups and the mass culture chambers were fed newly-hatched Artemia (Macau, Brazil strain; Johns, et al., 1980).

A one-way analysis of variance (Snedecor and Coch- 
ran, 1967) was computed to determine the effects of temperature on larval development. If significant differences (at $P=0.05$ ) were found in development times, a Duncan's Multiple Range test was used to determine where the differences occurred (Snedecor and Cochran, 1967). Data on the effects of temperature on intermolt duration were fitted to a log-inverse Bélehrádek model (Alderdice and Velsen, 1978). This modified model,

$$
\ln \mathrm{P}=\ln \mathrm{k}+\mathrm{b} \ln (\mathrm{X}-\mathrm{C})
$$

with $P$ being the percent development/day, $X$ the test temperature, $\mathrm{C}$ an estimate of the low temperature threshold for development, and $\mathrm{k}$ and $\mathrm{b}$ constants, allowed for linearization of the data and subsequent least square linear regression analysis. The resulting fitted regression lines were tested for equality of regression using analysis of covariance (Snedecor and Cochran, 1967).

Carapace length was taken as the maximum distance between the rostral spine (in a region just above the eyes) and the ventrolateral margin of the carapace. Length measurements were made on approximately 25 larvae per treatment per larval stage. Differences in carapace length for larvae cultured under the various treatments were tested using a one-way analysis of variance. Where significant differences were found, a Duncan's multiple range test was used to determine at which temperature and salinity condition the differences occurred.

The percent increase in carapace length following ecdysis was calculated as the percent difference between the mean length of two contiguous zoeal stages (post-molt length - pre-molt length/pre-molt length $\times$ $100 \%$ : Mauchline, 1976). Tests for the constancy of the growth increment were made with data collected for larvae reared at $15^{\circ} \mathrm{C} / 30 \%$ S since sufficient growth data were available only for this condition.

Hiatt growth diagrams, which relate post-molt to pre-molt size, were produced using least-square linear regression analysis (Hiatt, 1948; Kurata, 1962). Mean pre-molt and post-molt values had to be used in this analysis since continuous data was not collected on individual larvae.

During measurement of the larval carapace, a routine check was made of stage-specific morphological characters, including the number of natatory setae on the first and second maxilliped, the armature of the telson and setation on the furcae of the telson to determine what effect temperature and salinity might have on developmental morphology. The above characteristics were considered to be predictable and reliable for use in distinguishing between the larval stages of the rock crab (Sastry, 1977).

\section{RESULTS}

Survival to the megalopa stage was consistently higher for larvae cultured in $30 \% \mathrm{~S}$ at temperatures between $15^{\circ}$ and $24{ }^{\circ} \mathrm{C}$. The rearing condition of $21^{\circ} \mathrm{C} /$ $30 \% \mathrm{~S}$ provided for the highest survival. Survival at $10^{\circ} \mathrm{C}$ was lower than at the other temperatures tested; nevertheless $20 \%$ of the larvae did survive to the megalopa stage (Fig. 2).

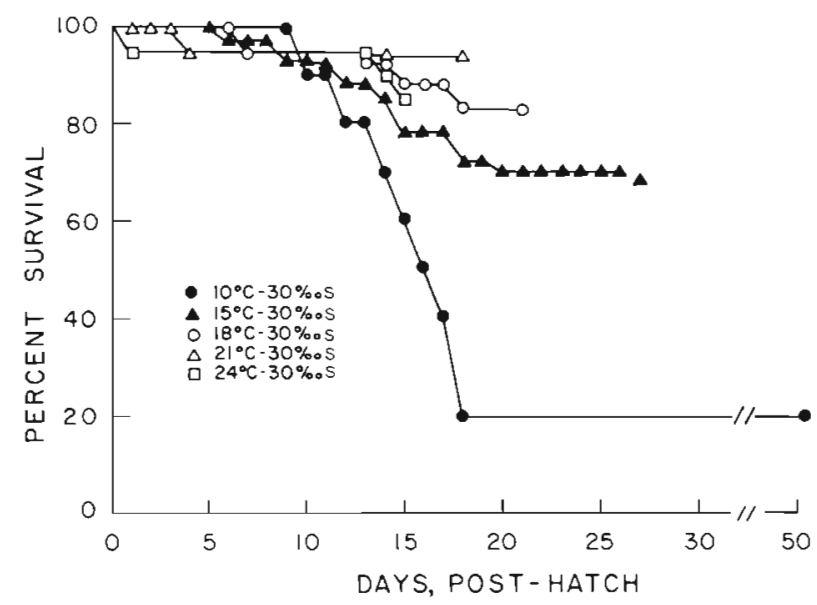

Fig. 2. Cancer irroratus. Survival of larvae to the megalopa stage cultured at various temperatures in $30 \% \mathrm{~S}$

Cancer irroratus larval development appears to be restricted to a narrow range of salinities (Fig. 3). At both $15^{\circ}$ and $24{ }^{\circ} \mathrm{C}$, survival was highest for larvae cultured in $30 \%$ S. As rearing temperature was increased, the deleterious effects of lowered salinity on larval development became magnified. At $15{ }^{\circ} \mathrm{C} / 25 \%$ S, $20 \%$ of the larvae survived to the megalopa stage,

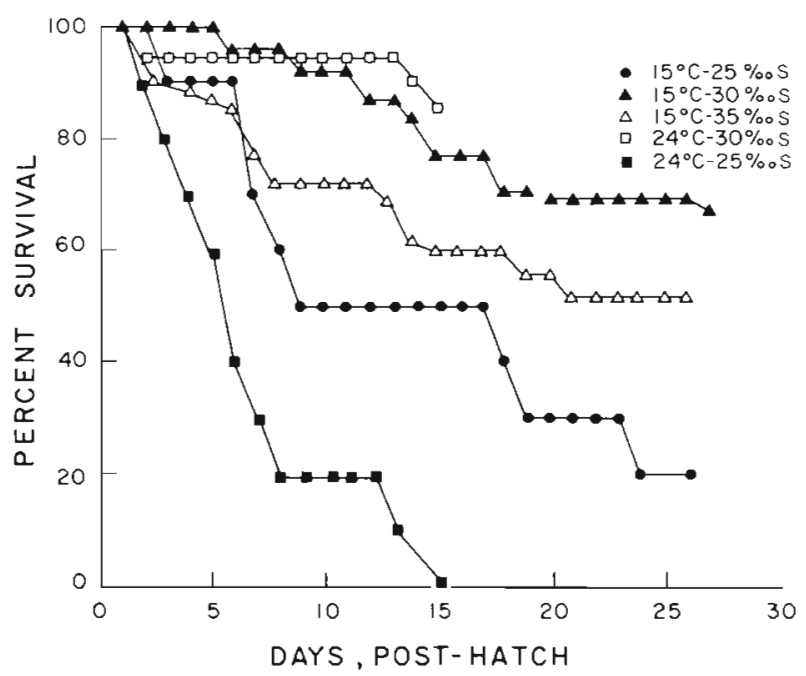

Fig. 3. Cancer irroratus. Survival of larvae to the megalopa stage cultured in various salinities at $15^{\circ}$ and $24^{\circ} \mathrm{C}$ 
while at $24{ }^{\circ} \mathrm{C} / 25 \%$ S, $100 \%$ mortality occurred prior to the fifth zoeal stage.

Temperature had a significant effect on the time required for development from hatch to the megalopa stage (Fig. 4; Table 1). Larvae reared at the higher temperatures $\left(18^{\circ}, 21^{\circ}\right.$ and $\left.24^{\circ} \mathrm{C}\right)$ tended to have similar development rates, but in general, as water temperature decreased, development time increased substantially. For instance, at $24^{\circ} \mathrm{C}, 16 \mathrm{~d}$ were required to

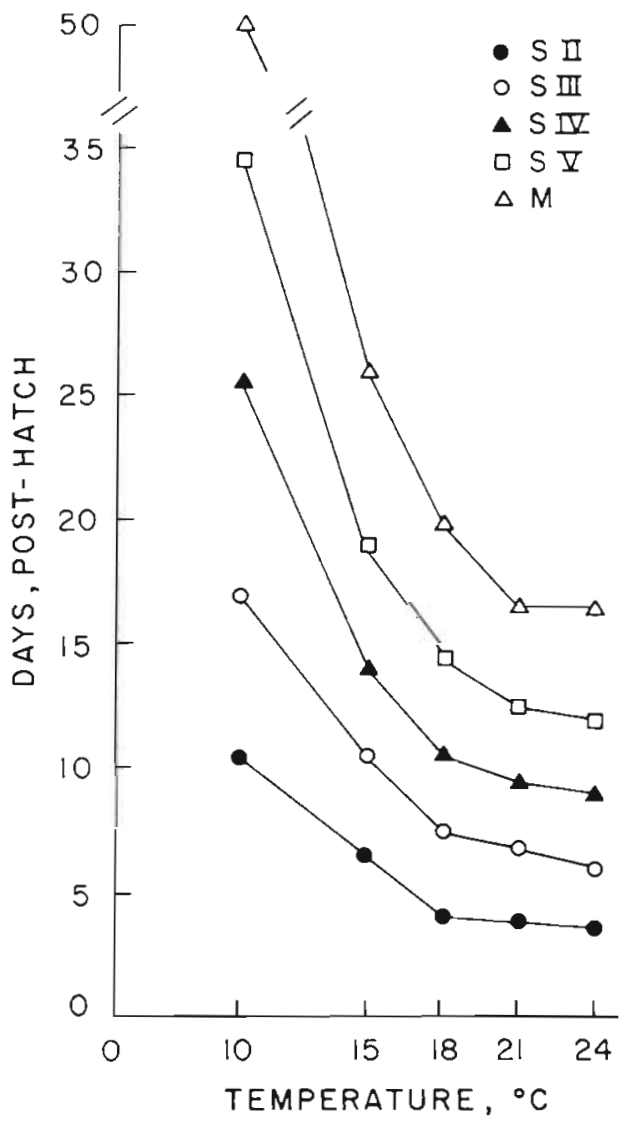

Fig. 4. Cancer irroratus. Development times from hatching to megalopa stage for larvae maintained at various temperatures in $30 \% \mathrm{~S}$

reach the megalopa stage, while at $10^{\circ} \mathrm{C}, 50 \mathrm{~d}$ were required to reach the same developmental stage. Temperature also had an effect on the intermolt duration within each zoeal stage (Table 2). Intermolt cycles for Stage I and Stage III larvae were more temperature sensitive than those of the other zoeal stages. In general, however, the similarity of the regression coefficients, b, for data fitted to the log-inverse Bélehrádek model indicates that the influence of a given temperature on intermolt duration is similar for all zoeal stages.

Larval size at hatching was found to be variable despite the fact that all eggs were incubated at $15^{\circ} \mathrm{C}$ and $30 \% \mathrm{~S}$ (Table 3). Larvae from female number 3 were found to be significantly larger $(P \leq 0.05)$ than
Table 1 Cancer irroratus. Aralysis of variance of development time of the larval stages from hatching. An asterisk after the ANOVA. $F$-Ratio indicates significant differences (at $\mathrm{P}=$ 0.05 ) in development times for larvae cultured at the various temperatures in $30 \% \mathrm{~S}$. Within a larval stage, temperature values grouped on the same line are not significantly different from each other

\begin{tabular}{ccc|}
\hline $\begin{array}{c}\text { Development } \\
\text { to larval stage }\end{array}$ & F-Ratio & Grouping \\
\hline II & $358^{\circ}$ & $24,21,18$ \\
& & 15 \\
& & 10 \\
III & $135^{\circ}$ & $24,21,18$ \\
& & 15 \\
IV & & 10 \\
& $324^{\circ}$ & $24,21,18$ \\
& & 15 \\
V & & 10 \\
& & 24,21 \\
& $200^{\circ}$ & 18 \\
M & & 15 \\
& & 24,21 \\
& & 18 \\
& $443^{\circ}$ & 15 \\
& & 10 \\
\hline
\end{tabular}

Table 2. Cancer irroratus. Parameter estimates for the loginverse Bélehrádek $(\ln \mathrm{P}=\ln \mathrm{k}+\mathrm{b} \ln (\mathrm{X}-\mathrm{C}))$ regression analysis used to determine the influence of temperature on intermolt duration of the zoeal stages. $\mathrm{k}=$ intercept at the $\mathrm{Y}$ axis, $b=$ regression coefficient, $r=$ correlation coefficient. $b$ values with the same grouping letter are not significantly (at $\mathrm{P}=0.05)$ different

\begin{tabular}{|ccccc|}
\hline $\begin{array}{c}\text { Larval } \\
\text { stage }\end{array}$ & $\mathrm{k}$ & $\mathrm{b}$ & Grouping & $\mathrm{r}$ \\
\hline I & -0.26 & 1.30 & $\mathrm{~A}$ & .97 \\
II & -0.28 & 1.12 & $\mathrm{~B}$ & .93 \\
III & -0.60 & 1.28 & $\mathrm{~A}$ & .86 \\
IV & -0.14 & 1.01 & $\mathrm{~B}$ & .85 \\
V & -0.70 & 1.12 & $\mathrm{~B}$ & .94 \\
\hline
\end{tabular}

Table 3. Cancer irroratus. Carapace size of newly-hatched Stage I zoeae incubated at $15^{\circ} \mathrm{C}$ and $30 \% \mathrm{~S}$. Data are presented as mean carapace length \pm 1 standard deviation. Means having the same grouping letter are not significantly different (at $\mathrm{P}=0.05$ ), (n): sample size

\begin{tabular}{|cccc}
\hline $\begin{array}{c}\text { Hatch } \\
\text { No. }\end{array}$ & $\begin{array}{c}\text { Carapace } \\
\text { length (mm) }\end{array}$ & (n) & Grouping \\
\hline 1 & $0.616 \pm .024$ & 19 & $\mathrm{~A}$ \\
2 & $0.603 \pm .019$ & 15 & $\mathrm{~A}$ \\
3 & $0.643 \pm .020$ & 37 & $\mathrm{~B}$ \\
4 & $0.607 \pm .018$ & 31 & $\mathrm{~A}$ \\
5 & $0.613 \pm .031$ & 40 & $\mathrm{~A}$ \\
\hline
\end{tabular}


those hatched from the other 4 females. Since significant differences in size at hatching could mask dissimilarities in growth that were solely due to environmental conditions, data collected from female number 3 were not included in any of the following analyses.

Growth during larval development was influenced by temperature, with the maximum carapace lengths found in larvae maintained at the mid-range of temperatures tested (Fig. 5, Table 4). For zoeal Stage II and III, individuals reared at $15^{\circ}, 18^{\circ}$ and $21^{\circ} \mathrm{C}$ were significantly larger $(\mathrm{P} \leq 0.05)$ than those reared at $10^{\circ}$ or $24^{\circ} \mathrm{C}$. After the molt to Stage IV, only larvae reared at $15^{\circ}$ and $18^{\circ} \mathrm{C}$ were larger than those maintained at the remaining temperatures. Finally, at zoeal Stage $V$, larvae at $18^{\circ} \mathrm{C}$ were the largest ( $\left.\mathrm{P} \leq 0.05\right)$, followed by individuals reared at $15^{\circ}, 21^{\circ}, 24^{\circ}$ and $10^{\circ} \mathrm{C}$ respectively; although there was no significant difference in size between $10^{\circ}$ and $24^{\circ} \mathrm{C}$ larvae. Larval growth, then, was favored in the intermediate range of temperatures tested, with the best growth being at $18{ }^{\circ} \mathrm{C}$.

Growth was also affected by salinity but in a pattern somewhat different than that found for temperature (Fig. 6, Table 5). For zoeal Stages II through IV, larvae cultured at $15^{\circ} \mathrm{C}$ in the higher salinities $(30$ and $35 \%$

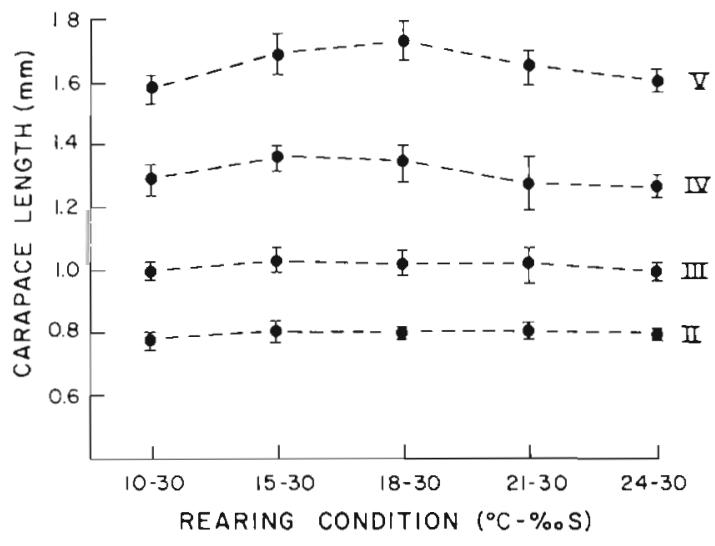

Fig. 5. Cancer irroratus. Carapace lengths for zoeal Stages II through $\mathrm{V}$ cultured at various temperatures in $30 \% \mathrm{~S}$. Values presented are the mean carapace length \pm 1 std. deviation

S) were significantly larger $(\mathrm{P} \leq 0.05)$ than those reared at $25 \% \mathrm{~S}$. At Stage $V$, however, larvae maintained in $25 \%$ S were significantly bigger ( $P \leq 0.05$ ) than those reared at $30 \% \mathrm{~S}$, with individuals at $35 \% \mathrm{~S}$ intermediate between the two.

The percent increase of carapace length following each succeeding molt decreased as zoeal development

Table 4. Cancer irroratus. Size of zoeal stages (SII-SV) cultured at various temperatures in $30 \%$ S. Data presented as mean carapace length \pm 1 standard deviation. Means within a particular zoeal stage having the same grouping letter are not significantly different (at $\mathrm{P}=0.05)$. ( $\mathrm{n}$ ): sample size

\begin{tabular}{|c|c|c|c|c|c|c|c|c|c|c|c|c|}
\hline $\begin{array}{c}\text { Culture } \\
\text { temperature }\left({ }^{\circ} \mathrm{C}\right)\end{array}$ & $\underset{(\mathrm{mm})}{\mathrm{SII}}$ & (n) & $\begin{array}{l}\text { Group- } \\
\text { ing }\end{array}$ & $\begin{array}{c}\text { SIII } \\
(\mathrm{mm})\end{array}$ & (n) & $\begin{array}{l}\text { Group- } \\
\text { ing }\end{array}$ & $\begin{array}{l}\text { SIV } \\
(\mathrm{mm})\end{array}$ & (n) & $\begin{array}{l}\text { Group- } \\
\text { ing }\end{array}$ & $\begin{array}{c}\mathrm{SV} \\
(\mathrm{mm})\end{array}$ & (n) & $\begin{array}{l}\text { Group- } \\
\text { ing }\end{array}$ \\
\hline 10 & $\begin{array}{r}0.778 \\
+\quad .019\end{array}$ & (35) & B & $\begin{array}{r}1.003 \\
\pm \quad .025\end{array}$ & $(40)$ & B & $\begin{array}{r}1.291 \\
\pm \quad .047\end{array}$ & (32) & B & $\begin{array}{r}1.584 \\
\pm \quad .039\end{array}$ & (27) & $\mathrm{D}$ \\
\hline 15 & $\begin{array}{r}0.805 \\
\pm \quad .029\end{array}$ & (49) & A & $\begin{array}{r}1.030 \\
\pm \quad .038\end{array}$ & (49) & $A$ & $\begin{array}{r}1.356 \\
\pm \quad .039\end{array}$ & $(50)$ & A & $\begin{array}{r}1.689 \\
+\quad .065\end{array}$ & (50) & B \\
\hline 18 & $\begin{array}{r}0.801 \\
\pm \quad .016\end{array}$ & $(20)$ & A & $\begin{array}{r}1.002 \\
\pm \quad .037\end{array}$ & (36) & A & $\begin{array}{r}1.338 \\
+\quad .060\end{array}$ & (34) & A & $\begin{array}{r}1.730 \\
\pm \quad .063\end{array}$ & (46) & $A$ \\
\hline 21 & $\begin{array}{r}0.804 \\
\pm \quad .023\end{array}$ & (21) & A & $\begin{array}{r}1.016 \\
\pm \quad .055\end{array}$ & (28) & A, B & $\begin{array}{r}1.272 \\
\pm \quad .073\end{array}$ & (33) & $\mathrm{B}, \mathrm{C}$ & $\begin{array}{r}1.648 \\
+\quad .060\end{array}$ & (38) & C \\
\hline 24 & $\begin{array}{r}0.786 \\
\pm \quad .018\end{array}$ & (33) & B & $\begin{array}{r}0.994 \\
\pm \quad .026\end{array}$ & (21) & B & $\begin{array}{r}1.261 \\
\pm \quad .034\end{array}$ & (33) & C & $\begin{array}{r}1.602 \\
\pm \quad .034\end{array}$ & (28) & $D$ \\
\hline
\end{tabular}

Table 5. Cancer irroratus. Size of zoeal stages (SII-SV) cultured at $15^{\circ} \mathrm{C}$ in various salinities. Data presented as mean carapace length \pm 1 standard deviation. Means within a particular zoeal stage having the same grouping letter are not significantly different (at $P=0.05)$. ( $(n)$ : sample size

\begin{tabular}{|c|c|c|c|c|c|c|c|c|c|c|c|c|}
\hline $\begin{array}{c}\text { Culture } \\
\text { salinity }(\%)\end{array}$ & $\begin{array}{c}\text { SII } \\
(\mathrm{mm})\end{array}$ & (n) & $\begin{array}{l}\text { Group- } \\
\text { ing }\end{array}$ & $\begin{array}{c}\text { SIII } \\
(\mathrm{mm})\end{array}$ & $(\mathrm{n})$ & $\begin{array}{c}\text { Group- } \\
\text { ing }\end{array}$ & $\begin{array}{c}\mathrm{SIV} \\
(\mathrm{mm})\end{array}$ & (n) & $\begin{array}{l}\text { Group- } \\
\text { ing }\end{array}$ & $\begin{array}{c}\text { SV } \\
(\mathrm{mm})\end{array}$ & (n) & $\begin{array}{l}\text { Group- } \\
\text { ing }\end{array}$ \\
\hline 25 & $\begin{array}{r}0.758 \\
+\quad .024\end{array}$ & (23) & B & $\begin{array}{r}0.979 \\
\pm \quad .038\end{array}$ & (15) & $C$ & $\begin{array}{r}1.306 \\
\pm \quad .042\end{array}$ & (37) & B & $\begin{array}{r}1.826 \\
+\quad .079\end{array}$ & (31) & A \\
\hline 30 & $\begin{array}{r}0.805 \\
\pm \quad .029\end{array}$ & (49) & A & $\begin{array}{r}1.030 \\
\pm \quad .038\end{array}$ & (49) & B & $\begin{array}{r}1.356 \\
\pm \quad .039\end{array}$ & (50) & $A$ & $\begin{array}{r}1.689 \\
\pm \quad .065\end{array}$ & (50) & $B$ \\
\hline 35 & $\begin{array}{r}0.801 \\
\pm \quad .020\end{array}$ & (33) & A & $\begin{array}{r}1.060 \\
+\quad .028\end{array}$ & (33) & $A$ & $\begin{array}{r}1.392 \\
\pm \quad .046\end{array}$ & (30) & A & $\begin{array}{r}1.802 \\
+\quad .074\end{array}$ & (20) & $A, B$ \\
\hline
\end{tabular}




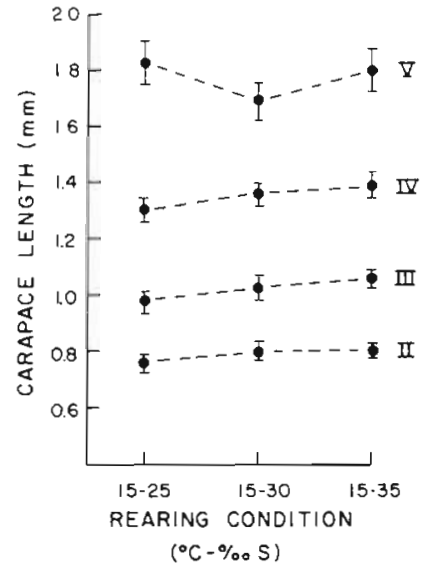

Fig. 6. Cancer irroratus. Carapace lengths for zoeal Stages II through $V$ reared in various salinities at $15^{\circ} \mathrm{C}$. Values presented are the mean carapace length \pm 1 std. deviation

progressed (Fig. 7). Linear regression analysis of these growth increment data for $15^{\circ} \mathrm{C}$ and $30 \% \mathrm{~S}$ cultured larvae indicated a slight reduction, with a regression line slope significantly different from 0 ( $F=9.45$; d.f. $3,14)$. Mean growth increments ranged from $32 \%$ for

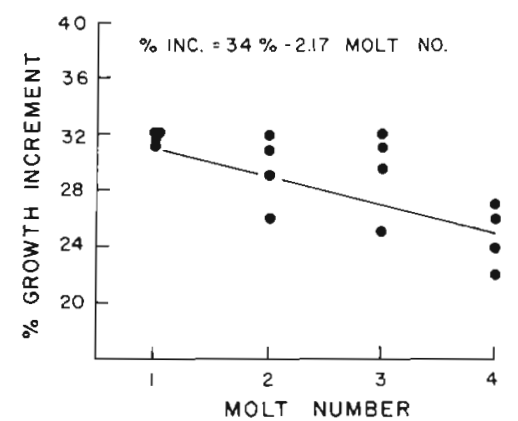

Fig. 7 Cancer irroratus. Changes in carapace length growth increment (expressed as \%) during larval development. The line represents raw data fitted by least-squares linear regression analysis

the Stage I - Stage II molt to $22 \%$ for the Stage IV Stage $V$ molt.

The relationship between post-molt and pre-molt size in rock crab larvae is presented in Figure 8 as Hiatt diagrams. Fit of the data to a linear regression model was good in all cases, with correlation coefficients being $>0.99$. Larvae reared at $15{ }^{\circ} \mathrm{C} / 25 \% \mathrm{~S}$ exhibited a significantly higher growth rate (slope $\leq$ $0.05 ; 1.53)$ than larvae reared in all other conditions tested (slopes from 1.18 to 1.27 ).

No environmentally-related variation was evident for the stage-specific morphological characters examined in this study. The independence from temperature or salinity influence on developmental morphology suggests that the process of morphogenesis is a conservative phenomenon, not influenced by the same environmental conditions which reduce absolute size.

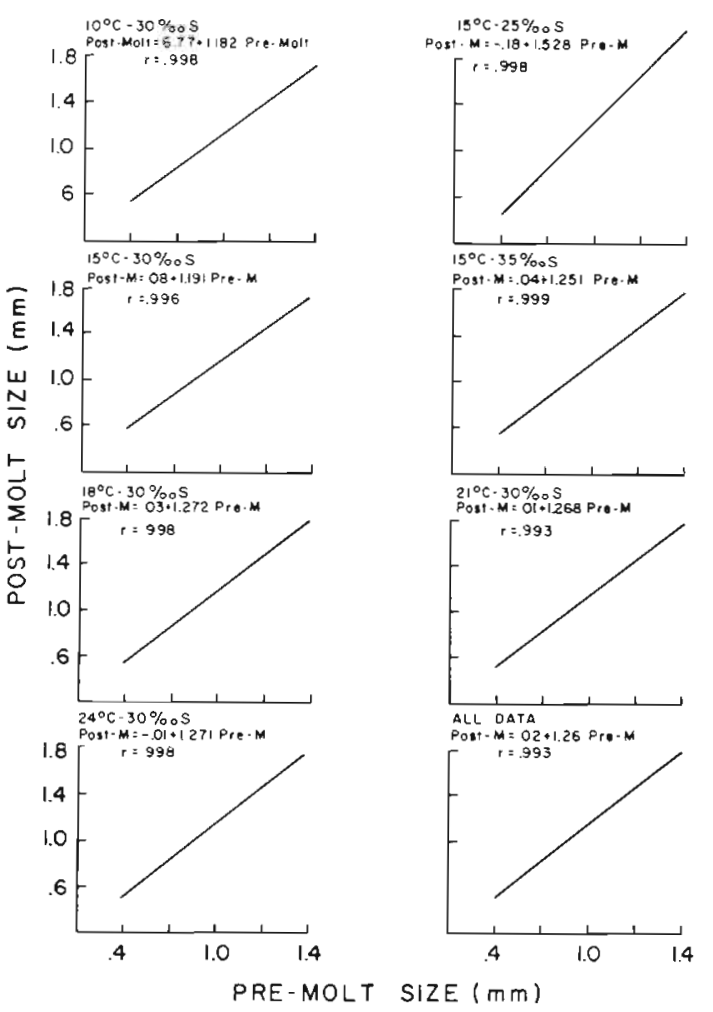

Fig. 8. Cancer irroratus. Hiatt diagrams for the larval stages cultured under various combinations of temperature and salinity. Lines represent raw data fitted by least-squares linear regression analysis

\section{DISCUSSION}

Survival and growth of rock crab larvae are dictated to varying degrees by temperature and salinity conditions, with temperature playing the more dominant role. Survival to the megalopa stage, molt frequency, intermolt duration, and larval size were all significantly influenced by temperature. Salinity modified both survival and size but had almost no effect on molting frequency or intermolt duration. Neither temperature nor salinity had any effect on developmental morphology.

The thermal tolerances, and survival rates for Cancer irroratus larvae reported in this study are considerably different from values previously reported in the literature for laboratory-cultured rock crab larvae. Sastry (1976) indicated an upper lethal limit of $20^{\circ} \mathrm{C}$ for rock crab larvae cultured under static culture conditions. In contrast, $84 \%$ of the larvae cultured at $24{ }^{\circ} \mathrm{C}$ in this study survived to the megalopa stage suggesting an upper thermal limit of greater than $24^{\circ} \mathrm{C}$. In addition, survival rates for larvae from the flow-through cultures used in this study were higher than in Sastry's static cultures under comparable temperature and salinity conditions. In $30 \% \mathrm{~S}$, percent survival for larvae 
cultured in the flow-through system were as follows: $10^{\circ} \mathrm{C}-20 \% ; 15{ }^{\circ} \mathrm{C}-68 \% ; 21{ }^{\circ} \mathrm{C}-94 \% ; 24{ }^{\circ} \mathrm{C}-84 \%$. Percent survival of larvae cultured under static conditions in $30 \%$ S were found to be: $10^{\circ} \mathrm{C}-15 \% ; 15^{\circ} \mathrm{C}-$ $60 \% ; 20^{\circ} \mathrm{C}-31 \% ; 25^{\circ} \mathrm{C}-0 \%$ (Sastry, 1976). Johns (1980) concluded that these differences in thermal tolerance and survival were primarily attributable to the laboratory culture techniques employed and not actual physiological differences. Flow-through culture techniques appear to provide $C$. irroratus larvae in better biological condition than do static culture techniques.

Maximum growth at metamorphosis was found at the mid-range of the thermal tolerance limits. Growth rates at higher $\left(24^{\circ} \mathrm{C}\right)$ and lower $\left(10^{\circ} \mathrm{C}\right)$ temperatures were less than those for larvae cultured in temperatures between $15-18^{\circ} \mathrm{C}$. Similar growth patterns have been reported by Rothlisberg (1979) for the larvae of Pandalus jordani and by Sweeney and Vannote (1978) for several species of aquatic insects. Sweeney and Vannote suggest that the reduction in size in arthropods at the thermal extremes is expected due to a disequilibrium in the balance between growth rate and timing of ecdysis. The results presented here suggest that this may be the case with rock crab larvae; however, critical evaluation awaits in-depth physiological and bioenergetic studies.

If these laboratory-determined survival and growth patterns for Cancer irroratus larvae were to occur in nature, the present findings indicate a pattern of growth and development more favorable to larvae hatched during the middle portion of the spawning season in waters of high salinity than at any other time. In the Narragansett Bay region, gravid rock crabs migrate to the mouth of the bay and adjacent offshore waters in the early spring to spawn (Jones, 1973; Reilly and Saila, 1978), with the spawning season continuing to late September (Bigford, 1979; A. D. Beck, unpubl.). Surface water temperatures during this time range from $9^{\circ}$ to $23^{\circ} \mathrm{C}$ (Jones, 1973; Bigford, 1979) while the salinity varies only between 29.5 and $32 \%$ S (Hillmann, 1964). Most gravid females, however, are collected between mid-June and mid-August when water temperatures vary between $14^{\circ}$ and $18^{\circ} \mathrm{C}$ (Jones, 1973). A similar pattern of peak spawning in rock crabs has also been reported by Krouse (1972) for the Gulf of Maine and by Scarratt and Lowe (1972) for the Northumberland Strait. It would seem then that the peak spawning period is timed to occur when temperature conditions are such that larval survival and growth are maximized, although some crab larvae are released at times when the environmental conditions are not as favorable.

Sastry and Vargo (1977) report seasonal variation in the temperature limits for development and survival of rock crab larvae. Larvae from summer hatches were less tolerant of cooler waters than were those individuals from either winter or spring hatches. Although no variation in the response to thermal conditions for rock crab larvae hatched at different seasons was found in this study, the data of Sastry and Vargo do indicate that some modifying factors in survival and growth may be present as the spawning season progresses.

Environmental conditions which might be encountered during dispersal of the pelagic larval phase can only be estimated since no data are available on the transport of Cancer irroratus larvae by currents. Survival of larvae transported into estuaries however, is probably low because of the stenohaline tolerances of the larvae. In the Narragansett Bay region, Cancerspp. larvae are abundant at the mouth of the bay ( $30 \%$ ) but very few larvae have been collected $1 \mathrm{~km}$ into the bay (Frolander, 1955; Hillman, 1964). Moreover, Sandifer (1973) collected rock crab larvae in lower Chesapeake Bay in salinities between 23.3 and $32 \% \mathrm{~S}$ with most larvae found in salinities above $25 \% \mathrm{~S}$.

The survival of larvae transported along the coast would be mainly dependent on the thermal range encountered since the salinity would be expected to remain high $(>30 \% \mathrm{~S})$ in these offshore waters. Using Bumpus's (1969) figure of $16 \mathrm{~km} \mathrm{~d}^{-1}$ for longshore current velocity for waters of the east coast of North America, an estimate of the distance rock crab larvae might be transported during development can be made. Since the pelagic phase of larval development in Cancer irroratus can vary between 17 and $50 \mathrm{~d}$ depending on temperature, larvae remaining in the plankton between these periods would be carried between 272 and $800 \mathrm{~km}$. Larvae spawned in $10^{\circ} \mathrm{C}$ waters off Narragansett Bay and transported in a southerly direction for up to $50 \mathrm{~d}$ could encounter temperatures between $10^{\circ}$ and $18^{\circ} \mathrm{C}$ (Walfurd and Wicklund, $1968)$, while larvae hatched in warmer waters $\left(20^{\circ} \mathrm{C}\right)$ would experience a temperature range of only $20^{\circ}$ to $23^{\circ} \mathrm{C}$ (Walfurd and Wicklund, 1968). These temperatures are well within the thermal tolerances of rock crab larvae. In terms of temperature and salinity then, it would seem that the dispersal of $C$. irroratus larvae from the spawning grounds would not be deleterious to their survival or development unless the larvae were carried into the low salinity waters of an estuary.

The dispersal of rock crab larvae during the peak spawning period (mid-June to mid-August) is of interest since any change in the thermal regime encountered during development might negate any size advantage that would have been gained by spawning in water temperature of $15^{\circ}$ to $18^{\circ} \mathrm{C}$. Calculation of the maximum southerly longshore dispersal range and the temperatures encountered during dispersal indicates that there would be little variation in the surface water 
temperatures (Walfurd and Wicklund, 1968). Therefore, rock crab larvae spawned in Rhode Island waters between June and August would experience both local and regional water conditions favorable for maximum growth. The competitive value that might be gained in these optimal growth conditions (viz. larger size) could include the ability to out-compete smaller-sized larvae for available food resources and the ability to avoid pelagic predators (Mullin and Brooks, 1970; Dodson, 1974; Kerfoot, 1975; Menge, 1975; Allan, 1976). Following metamorphosis and during initial settlement to the benthic environment, size may also play an important role in both intra- and interspecific competition for resources (Mileikovsky, 1970).

In summary, the peak spawning period of Cancer irroratus in Rhode Island waters centers around that portion of the season when larval wastage would be minimized and recruitment to the parental and regional populations would be maximized.

Acknowledgements. This study was part of the dissertation submitted to the University of South Carolina in partial fuIfillment of the requirements of the degree of Doctor of Philosophy. I wish to acknowledge the helpful comments and criticisms of colleagues and thesis committee members: Drs. W. B. Vernberg, D. C. Miller, S. Stancyk, P. DeCoursey, R. Gardner, A. N. Sastry, J. Scott and W. J. Berry. Portions of this research were supported by a United States Environmental Protection Agency Fellowship.

\section{LITERATURE CITED}

Alderdice, D. F. (1972). Factor combinations-responses of marine poikilotherms to environmental factors acting in concert. In: Kinne, O. (ed.) Marine ecology, Vol. 1, Environmental factors, Part 3. Wiley, London, pp. $1659-1722$

Alderdice, D. F., Velsen, F. P. J. (1978). Relation between temperature and incubation time for eggs of Chinook salmon (Oncorhynchus tshawytscha). J. Fish. Res. Bd Can. 35: $69-75$

Allan, J. D. (1976). Life history patterns in zooplankton. Am. Nat. 110: 165-180

Bigford, T E. (1979). Synopsis of biological data on the rock crab, Cancer irroratus Say. NOAA Tech. Rep. NMFS Circular 426: 26

Bumpus, D. F. (1969). Surface drift on the Atlantic continental shelf of the United States, 1960-1967. Unpubl. Tech. Rep., Woods Hole Oceanographic Institution, Ref. 69-18

Dodson, S. I. (1974). Zooplankton competition and predation: An experimental test of the size-efficiency hypothesis. Ecology 55: 605-613

Frolander, H. T. (1955). The biology of the zooplankton of the Narragansett Bay area. Ph. D. thesis, Brown University, Providence, Rhode Island.

Hiatt, R. W. (1948). The biology of the lined shore crab, Pachygrapsus crassipes Randall. Pacif. Sci. 2: 135-213

Hillman, N. S. (1964). Studies on the distribution and abundance of decapod larvae in Narragansett Bay, Rhode Island, with consideration of morphology and mortality. M. S. thesis, University of Rhode Island, Kingston

Johns, D. M. (1980). Larval development and bioenergetics of
Cancer irroratus (Say) larvae under optimal and sub-optimal conditions of temperature and salinity. Ph. D. thesis, University of South Carolina, Columbia

Johns, D. M., Peters, M. E., Beck, A. D. (1980). Internatıonal study on Artemia. VI. Nutritional value of geographical and temporal strains of Artemia: Effects on survival and growth of two species of brachyuran larvae. In: Persoone, G., Sorgeloos, P., Roels, O., Jaspers, E. (eds) The brine shrimp, Artemia, Vol. 3, Ecology, culturing, use in aquaculture. Universa Press, Wetteren, Belgium, pp. 219-304

Jones, C. (1973). The ecology and metabolic adaptations of Cancer irroratus Say. M. S. thesis, University of Rhode Island, Kingston

Kerfoot, W C. (1975). Implications of copepod predation. Limnol. Oceanogr. 22: 316-325

Kinne, O. (1970). Temperature. Animals: Invertebrates. In: Kinne, O. (ed.) Marine ecology, Voì. I, Cultivation, Part. 1. Wiley, London, pp. 405-514

Kinne, O. (1971). Salinity. Animals: Invertebrates. In: Kinne, O. (ed.) Marine ecology, Vol. I, Cultivation, Part 2. Wiley, London, pp. 821-995

Krouse, J. S. (1972). Some life history aspects of the rock crab, Cancer irroratus, in the Gulf of Maine. J. Fish. Res. Bd Can. 29: 1479-1482

Kurata, H. (1962). Studies on the age and growth of Crustacea. Bull. Hokkaido Res. Fish. Res. Lab. 24: 1-115

Mauchline, J. (1976). The Hiatt growth diagram for Crustacea. Mar. Biol. 35: 79-84

Menge, B. A. (1975). Brood or broadcast? The adaptive significance of different reproduction strategies in the two intertidal sea stars Leptasterias hexactis and Pisaster ochraceus. Mar. Biol. 37: 87-100

Mileikovsky, S. A. (1970). Seasonal and daily dynamics in pelagic larvae of marine shelf bottom invertebrates in nearshore waters of Kandalaska Bay (White Sea). Mar. Biol. 5: 180-194

Mullin, M. M., Brooks, E. R. (1970). The effect of concentration of food on body weight, cumulative ingestion and rate of growth of the marine copepod, Calanus helgolandicus Limnol. Oceanogr. 15: 748-755

Reilly, P. N., Saila, S. B. (1978). Biology and ecology of the rock crab, Cancer irroratus in southern New England waters. Crustaceana 34: 121-140

Rothlisberg, P. C. (1979). Combined effects of temperature and salinity on the survival and growth of the larvae of Pandalus jordani (Decapoda: Pandalidae). Mar. Biol. 54: 125-134

Sandifer, P. A. (1973). Distribution and abundance of decapod crustacean larvae in the York River estuary and adjacent lower Chesapeake Bay, Virginia, 1968-1969. Chesapeake Sci. 14: 235-257

Sastry, A. N. (1970). Culture of brachyuran crab larvae using a recirculating sea water system in the laboratory. Helgoländer wiss. Meeresunters. 20: 406-416

Sastry, A. N. (1976). The larval development of the rock crab, Cancer irroratus Say, 1817, under laboratory conditions (Decapoda: Brachyura). Crustaceana 32: 155-168

Sastry, A. N. (1977). Effects of constant and cyclic temperature regimes on the pelagic larval development of a brachyuran crab. In: Esch, G. W., McFarlane, R. W. (eds) Thermal ecology II, ERDA symposium series, 40 (Conf. 750425) National Technical Information Service, U.S. Department of Commerce, Springfield, Va., USA, pp. 81-87

Sastry, A. N., Vargo, S. L. (1977). Variation in physiological response of crustacean larvae to temperature. In: Vernberg, F. J., Calabrese, A., Thurberg, F. P., Vernberg, W. B. 
(eds) Physiological response of marine biota to pollutants. Academic Press, New York, pp. 401-423

Scarratt, D. J., Lowe, R. (1972). Biology of the rock crab (Cancer irroratus) in Northumberland Strait. J. Fish. Res. Bd Can. 29: 161-166

Snedecor, G. W., Cochran, W G. (1967). Statistical methods, Iowa State University Press, Ames, lowa

Strathmann, R. R. (1977). Toward understanding complex life cycles of benthic invertebrates. In: Costlow, J. D. Jr. (ed.) The ecology of fouling communities, U.S. Office of Naval Research, U.S. Government Printing Office, Washington, D.C., pp. $1-20$
Sweeney, B. W., Vannote, R. L. (1978). Size variation and the distribution of hemimetabolous aquatic insects: Two thermal equilibrium hypotheses. Science, N.Y 200: 444-446

Thorson, G. (1950). Reproductive and larval ecology of marine bottom invertebrates. Biol. Rev. 25: 1-45

Walfurd, L. A., Wicklund, R. I. (1968). Monthly sea temperature structure from the Florida Keys to Cape Cod. In: Webster, $W$ (ed.) Serial atlas of the marine environment American Geographic Society, New York, Folio 15

Williams, A. B. (1965). Marine decapod crustaceans of the Carolinas. Fish. Bull. 65: 1-298

This paper was presented by Professor J. Vemberg; it was accepted for printing on December 22, 1980 